\begin{tabular}{|c|l|}
\hline Title & U samaro Takakura (1867-1944), Japanese pioneer nemertean researcher \\
\hline Author(s) & Kajihara, Hiroshi \\
\hline Citation & Archives of Natural History, 31, 208-213 \\
\hline Issue Date & 2004 \\
\hline Doc URL & http://hdl.handle.net/2115/43920 \\
\hline Type & article \\
\hline File Information & Kajihara_2004.pdf \\
\hline
\end{tabular}

Instructions for use 


\title{
Usamaro Takakura (1867-1944), Japanese pioneer nemertean researcher
}

\author{
HIROSHI KAJIHARA \\ Division of Biological Sciences, Graduate School of Science, Hokkaido University, 060-0810 Sapporo, Japan \\ (e-mail: kazi@sci.hokudai.ac.jp)
}

\begin{abstract}
Usamaro Takakura (1867-1944), a pioneer Japanese specialist on nemerteans (phylum Nemertea), established 14 new species and one new genus, Coeia. This paper gives a brief outline of his life and publications, together with the list of his new taxa, the type materials for which are all lost.
\end{abstract}

KEY WORDS: biography - Nemertea - Japan - Takakura's duct - Coeia

\section{INTRODUCTION}

Usamaro Takakura (1867-1944) was the first Japanese expert on nemerteans (phylum Nemertea) which are unsegmented soft-bodied invertebrates, sometimes called ribbon worms, of which approximately 1,150 species are known (Gibson, 1995). They are mainly free-living, but a few are parasitic, and while mostly marine (often benthic), a few species inhabit freshwater or terrestrial habitats.

Primarily from material collected on the Pacific coast of Honshu, Japan, Takakura reported 25 species, of which 14 were new to science, and one new genus (Takakura, 1897a, 1897b, $1898,1910,1922,1933)$. He is remembered for his discovery of a unique male reproductive organ in the parasitic nemerteans, belonging to the family Carcinonemertidae, which live on the gills and egg masses of various marine crabs. Humes' (1941) proposal' to call this organ "Takakura's duct" has been widely accepted, and this technical term is now commonly used among researchers (e.g. Wickham and Kuris, 1988; Shields, 2001). Takakura is honoured in the scientific names of the sea-horse (or sea-dragon) Hippocampus takakurai Tanaka, 1916 and the crab Lophoplax takakurai Sasaki, 1935.

\section{BRIEF BIOGRAPHY}

The son of Viscount Takakura, Usamaro Takakura (Figure 1) was born in Kyoto on 19 February 1867. Little is known about his primary and secondary education. He entered the College of Science, Imperial University (now Faculty of Science, University of Tokyo) in 1891, and apparently began to stay at the Misaki Marine Biological Station in his second year (Isono, 1988).

On 10 July 1894, Takakura completed his undergraduate studies for a bachelor's degree in zoology under Professor Kakichi Mitsukuri ${ }^{2}$ and Professor Isao Îjima ${ }^{3}$. He went on to the Graduate School, but withdrew from it on 10 July 1899 before completion of his Ph.D. From September 1899, he held the position of Professor of Zoology at the Higher Normal School (renamed Tokyo Higher Normal School in 1902). From 1930, Takakura concurrently held the post of professor at Tokyo University of Literature and Science. 


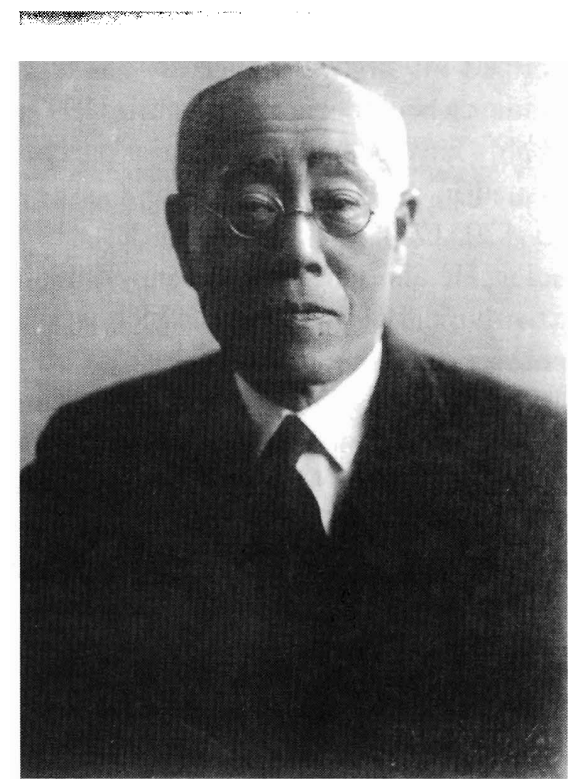

Figure 1. Usamaro Takakura (1867-1944), in his early sixties (reproduced from Hakubutsugaku zasshi 35 (1937)).

For 30 years Takakura taught natural history. He and his colleague and fellow lecturer, Asajirô $\mathrm{Oka}^{4}$, were close friends and their desks were placed side by side in the same office. They hiked together on the outskirts of Tokyo almost every holiday, and it was their custom on these trips to have soba ${ }^{5}$ for lunch (Oka, 1925). Because of their close friendship, the atmosphere in the Department of Natural History at Tokyo Higher Normal School was congenial and relaxed, and this was envied by students in the other departments (Umemoto, 1937).

Unfortunately, Takakura suffered family tragedies. He and his wife lost five of their eight children one after another, and the death of his wife on 10 October 1925 was a terrible blow (Tominaga, 1925). He lived with two of his surviving daughters at his home in Katsushika, Tokyo, until his death from pneumonia on 17 March 1944 (Takashima, 1944).

Takakura bequeathed all his nemertean specimens and literature to Tokyo University of Literature and Science so that it would possess the best collection in the Orient (Takashima, 1944). The nemertean collection was catalogued around 1957 by Sudzuki. ${ }^{6}$ By that time, however, the collection was in bad condition, with many labels lost and most specimens dried or damaged. ${ }^{7}$ Today, only four of his non-type specimens of nemerteans can be found in the University of Tsukuba, the successor of Higher Normal School, Tokyo Higher Normal School and Tokyo University of Literature and Science. The fate of Takakura's collection thus remains uncertain. ${ }^{8}$

\section{BRIEF OUTLINE OF TAKAKURA'S PUBLICATIONS ON NEMERTEANS}

Takakura published a total of 73 papers, textbooks and translated articles. ${ }^{9}$ His first work on nemerteans appeared in 1895 when he was 28 years old and contains his original view on 
nemertean systematics (Takakura, 1895), although this is largely based on Bürger's (1895) classification. In 1897 he described his first new species (Takakura, 1897b), which he had preliminarily reported as an undescribed species (Takakura, 1897a). His 1898 paper is his principal work, and would probably have constituted a major part of the doctoral thesis which he did not complete; it was issued in parts in five different issues of Zoological magazine (volume 10: nos 112, 114, 116, 120, 122). In it, Takakura described 21 anoplan nemerteans, of which eleven were new species. He announced at the end of the last article that the studies would be continued in the next volume, but the sequel, which would have contained descriptions of enoplan species, was never published. After Takakura obtained a teaching position in 1899, he described a further new species in 1910 and another in 1922, both in memorial numbers of Zoological magazine ${ }^{10}$, commemorating in the names two of his former supervisors, Mitsukuri ${ }^{2}$ and Ijima $^{3}$, respectively. In 1932 he published a short review of freshwater nemerteans (Takakura, 1932). Interestingly, Takakura studied a freshwater heteronemertean from Taiwan, which has never been described or named. He stated as follows (Takakura, 1932; present author's translation):

All of the freshwater nemerteans known until lately belong to the genus Prostoma. Recently, however, Beauchamp studied a nemertean species that lives abundantly in a pond in the Buitenzorg Botanical Garden, Java, and found it to be an unknown form. He published it as a new genus and species, Planolineus exsul. Remarkably, this new genus is closely related to Lineus, belonging to the Heteronemertini, whereas Prostoma belongs to the Metanemertini. Last spring Mr Sadae Takahashi, the teacher at the Taipei First Normal School, brought me a living freshwater nemertean specimen. He has subsequently sent me several specimens fixed by various methods, and thus given me the opportunity to study them. This form belongs to the Heteronemertini and is closely related to the genus Lineus. Although this species resembles the Java species, it is now under investigation whether or not this is conspecific with the latter.

Takakura's last scientific paper was a report on two species of nemerteans collected by the Northern Kurile Islands Scientific Expedition"t (Takakura, 1933).

\section{ACKNOWLEDGEMENTS}

I am indebted to Professor Emeritus Kouichi Sekiguchi, University of Tsukuba, for information about the circumstances during the relocation of Tokyo University of Education to Tsukuba City, and to Professor Minoru Sudzuki, Nihon University, for sharing recollections. I also express my sincere gratitude to Dr Kensuke Yahata, University of Tsukuba, for permitting my visit to study the nemertean specimens at the University of Tsukuba. I gratefully acknowledge Professor Emeritus Ray Gibson, Liverpool John Moores University, Dr Janet Moore, University of Cambridge, and Dr Matthew H. Dick, Hokkaido University, for their invaluable comments on earlier drafts of this paper.

\section{NOTES}

' Arthur Grover Humes (1916-1999), Professor Emeritus of Biology, Boston University, completed a monograph of the parasitic nemertean family Carcinonemertidae when he was a Ph.D. student at the University of Illinois, although his major interest during the rest of his long research career remained in copepod crustaceans, particularly those associated with other marine organisms (Duncan, 1999).

${ }^{2}$ Kakichi Mitsukuri (1858-1909) went to the USA in 1873 and entered Yale University in 1877 to study zoology under A. E. Verrill and S. I. Smith. In 1881 he visited England for two months to study under F. M. Balfour at the University of Cambridge. He was the third Professor of Zoology at the University of Tokyo, following Edward Sylvester Morse and Charles Otis Whitman, and the first Director of Misaki Marine Biological Station (1898-1904).

${ }^{3}$ After graduating from the University of Tokyo (1881), Isao îjima (1861-1921) went to Germany (1882-1884) 
to study under K. G. F. R. Leuckart at Leipzig University. He held the position of Professor at the University of Tokyo (1886-1921), and was the second Director of Misaki Marine Biological Station (1904-1921).

${ }^{4}$ After specializing in zoology in the College of Science, Imperial University of Tokyo, Asajirô Oka (1868-1944) went to Germany to study under A. Weismann at Freiburg University and K. G. F. R. Leuckart at Leipzig University. After returning to Japan, he held the positions of Professor at the Old Yamaguchi High School, Tokyo Higher Normal School, and Tokyo University of Literature and Science. He was known not only for his studies on leeches, ascidians and bryozoans, but also for popularization of the theory of evolution in Japan.

${ }^{5}$ A thin buckwheat noodle, a traditional Japanese food.

${ }^{6}$ Minoru Sudzuki (b. 1930) graduated from Saitama University in 1953 and gained his Ph.D. in 1958 at the Tokyo University of Education. Although he is a rotiferan specialist, he published a paper on freshwater nemerteans (Sudzuki, 1953), and this led his supervisor to ask him to prepare the catalogue of the nemertean collection at Tokyo University of Education when he was a graduate student. Unfortunately, the catalogue has been lost.

${ }^{7}$ M. Sudzuki to HK, pers. comm., 4 August 2002.

${ }^{8} \mathrm{~K}$. Sekiguchi to HK, pers. comm., 23 April 2002. During the relocation from Tokyo to Tsukuba, many specimens were thrown out before there was time for a proper appraisal for their value. Dr Sekiguchi, an Assistant Professor at the time of the relocation, with a strong sense of mission desperately rescued important specimens. He salvaged a number of ascidian specimens, which later turned out to be Oka's types, from the dump yard on the university campus. Takakura's nemertean collection, however, must have been discarded during this period without attracting anybody's attention.

${ }^{9}$ Copies of Takakura's publications can be obtained upon request to the present author via e-mail.

${ }^{10}$ During its 95-years-history, Zoological magazine issued eight memorial numbers commemorating distinguished Japanese zoologists (Isono, 1988: 62).

"The Northern Kurile Islands Scientific Expedition was carried out during July and August 1931 by $\mathrm{Mr}$ Kazuo Kiba, Zoological Laboratory of Tokyo University of Literature and Science, Mr Kiichi Okada, Botanical Laboratory of the Imperial Fisheries Institute, and Mr Denjirô Hasegawa, an alpinist, under the auspices of the Ôsaka Mainichi Shinbun and the Tokyo Nichinichi Shinbun newspaper companies (Anonymous, 1931). It yielded 719 species of animals and plants, including three new species of insects and one new vascular plant. The results were published in Bulletin of the Biogeographical Society of Japan 4 (19??), and consisted of 27 papers by 24 experts including Takakura.

\section{REFERENCES}

ANONYMOUS, 1931 Kitachishima gakujutsu tanken [Northern Kurile Islands Scientific Expedition; in Japanese]. Kagaku 1: 267-268.

BÜRGER, O., 1895 Die Nemertinen des Golfes von Neapel und der angrenzenden Meeres-Abschnitte. Fauna und Flora des Golfes von Neapel 22: 1-743.

CHERNYSHEV, A. V., 1992 O nazvaniyakh nekotoruikh nemertin [On the names of some nemerteans; in Russian]. Zoologicheskii zhurnal 71: 134-136.

DUNCAN, T., 1999 Arthur G. Humes (1916-1999). Southern California Association of Marine Invertebrate Taxonomists newsletter 18: 5-6.

GIBSON, R., 1995 Nemertean genera and species of the world: an annotated checklist of original names and description citations, synonyms, current taxonomic status, habitats and recorded zoogeographic distribution. Journal of natural history 29: 271-562.

HUMES, A. G., 1941 The male reproductive system in the nemertean genus Carcinonemertes. Journal of morphology 69: $443-454$.

ISONO, N., 1988 Misaki rinkai jikkenjo wo kyorai shita hitotachi-- Nihon ni okeru dôbutsugaku no tanjou [Those who came and went to the Misaki Marine Biological Station - The birth of zoology in Japan; in Japanese]. Gakujutsu Shuppan Centre, Tokyo. Pp vi, 230.

OKA, A., 1925 Tomo ni sugoshita nijûgo nen [Twenty five years spent together; in Japanese]. Hakubutsugaku zasshi 32: 1-2.

RISER, N. W., 1991 New Zealand nemertes from kelp holdfasts: Heteronemertinea II. Notospermus geniculatus (Delle Chiaje, 1828) n. comb. New Zealand journal of zoology 18: 427-438. 
SHIELDS, J. D., 2001 Ovicides julieae n. gen., n. sp. (Nemertea: Carcinonemertidae) on xanthid crabs from the Great Barrier Reef, Australia. Journal of crustacean biology 21: 304-312.

SUZDUKI, M., 1953 Nihonsan tansui himomushi ni tsuite [On Japanese fresh-water nemerteans; in Japanese]. Zoological magazine 62: 212-219.

TAKAKURA, U., 1895 Himomushi no bunnrui [Classification of nemerteans; in Japanese]. Zoological magazine 7: 192-195.

TAKAKURA, U., 1897a Nihonsan Malacobdella (nov. sp?) ni tsukite [On the Japanese Malacobdella (nov. sp?); in Japanese]. Zoological magazine 9: 233-237.

TAKAKURA, U., 1897b On a new species of Malacobdella (M. japonica). Annotationes japonenses 1: 105112.

TAKAKURA, U., 1898 Misaki kinbou-san himomushi (Nemertini) no bunrui [Classification of nemerteans of the vicinity of Misaki; in Japanese]. Zoological magazine 10: 38-44, 116-120, 184-187, 331-337, 424-429.

TAKAKURA, U., 1910 Kisei himomushi no ichi shinshu [A new species of parasitic nemertean; in Japanese]. Zoological magazine 22: 111-116.

TAKAKURA, U., 1922 Honpou-san himomushi no ichi shinzoku ni tsukite [On a new genus of nemertean from Japan; in Japanese]. Zoological magazine 34: 419-422.

TAKAKURA, U., 1932 Tansui himomushi no hanashi [On the freshwater nemerteans; in Japanese]. Hakubutsugaku zasshi 30: 4-6.

TAKAKURA, U., 1933 Kitachishima no himomushi rui [Nemerteans of the Northern Kurile Islands; in Japanese]. Bulletin of the Biogeographical Society of Japan 4: 226-227.

TAKASHIMA, H., 1944 Takakura Usamaro sensei wo shinobu [Obituary of Professor Takakura Usamaro; in Japanese]. Zoological magazine 56: 72-73.

TOMINAGA, S., 1925 Takakura sensei kinengou hakkan ni saishite [On the issue of the memorial number for Professor Takakura; in Japanese]. Hakubutsugaku zasshi 32: 88-91.

UMEMOTO, H., 1937 Omoide to kansha [Memories and appreciation; in Japanese]. Hakubutsugaku zasshi 35: $57-59$.

WICKHAM, D. E. and KURIS, A. M., 1988 Diversity among nemertean egg predators of decapod crustaceans. Hydrobiologia 156: 23-30.

YAMAOKA, T., 1940 The fauna of Akkeshi Bay, IX, Nemertini. Journal of the Faculty of Science, Hokkaido University, series 6, zoology, 7: 205-263.

Received: 18 December 2002. Accepted: 23 December 2003.

\section{APPENDIX: SPECIES ESTABLISHED BY TAKAKURA}

Carcinonemertes mitsukurii Takakura, 1910. Obtained from the egg mass of the crab Eriocheir japonicus De Haan, 1835. Type locality: Mouth of the River Minato, Tateyama Bay, Chiba.

Carinella punctata Takakura, 1898. Redescribed by Yamaoka (1940) as Tubulanus punctatus (Takakura, 1898). Type locality: Jôgashima, Kanagawa.

Cerebratulus carnosus Takakura, 1898. Type locality: Misaki Port and Koajiro Bay, Kanagawa.

Cerebratulus communis Takakura, 1898. Type locality: Misaki Port, Koajiro Bay, Bishamon Bay and Matsuwa Port, Kanagawa.

Coeia ijimai Takakura, 1922. Type locality: Tateyama Bay, Chiba. The genus Coeia Takakura, 1922, currently monotypic, was simultaneously established; the generic name was a tribute to Wesley Roswell Coe (1869-1960), Takakura's contemporary nemertean researcher at Yale University.

Lineus alborostratus Takakura, 1898. Type locality: Misaki, Kanagawa. The Japanese vernacular name of this species bears Takakura's name as Takakura-himomushi.

Lineus bipunctatus Takakura, 1898. Type locality: Jôgashima, Kanagawa.

Lineus caputornatus Takakura, 1898. Type locality: Jôgashima, Kanagawa.

Lineus fuscoviridis Takakura, 1898. Type locality: Misaki and Jôgashima, Kanagawa. 
Lineus mitellatus Takakura, 1898. Synonymised with Notospermus geniculatus (Delle Chiaje, 1828) by Riser (1991). Type locality: Misaki and Jôgashima, Kanagawa.

Lineus subcingulatus Takakura, 1898. Type locality: Kaojira Bay, Kanagawa.

Malacobdella japonica Takakura, 1897. Reported as Malacobdella sp. in Takakura (1897a), but fully described in Takakura (1897b) from the mantle cavity of the bivalve Mactra sachalinensis Schrenck, 1862. Type locality: Kujûkuri, Chiba.

Micrura dorsovittata Takakura, 1898. Type locality: Jôgashima, Kanagawa.

Micrura festiva Takakura, 1898. Synonymised with Micrura bella (Stimpson, 1857) by Yamaoka (1940), but Chernyshev (1992) regards it as a valid species. Type locality: Jôgashima, Kanagawa. 